\title{
Mix Design Procedure for Self Compacting Concrete
}

\author{
${ }^{1}$ Krishna Murthy.N, ${ }^{2}$ Narasimha Rao A.V, ${ }^{3}$ Ramana Reddy I.Vand ${ }^{4}$ Vijaya sekhar \\ Reddy.M \\ Engineering Department, Yogi Vemana University, Kadapa, \& Research Scholar of S.V.University ,Tirupati, India \\ Professor, Department of Civil Engineering, S.V. University, Tirupati, India \\ Professor,Department of Civil Engineering, S.V. University, Tirupati, India \\ HOD, Department of Civil Engineering, SKIT, Srikalahasti, India
}

\begin{abstract}
Self-compacting concrete(SCC) possesses enhanced qualities and improves productivity and working conditions due to elimination of compaction. SCC is suitable for placing in structures with congested reinforcement without vibration and it helps in achieving higher quality of surface finishes. However utilization of high reactive Metakaolin and Flyash as an admixtures as an effective pozzolan which causes great improvement in the pore structure, also compactibility is affected by the characteristics of materials and the mix proportions, it becomes necessary to evolve a procedure for mix design of SCC.In this paper presents an experimental procedure for the design of self-compacting concrete mixes. The relative proportions of key components are considered by volume rather than by mass. A simple tool has been designed for self compacting concrete (SCC) mix design with $29 \%$ of coarse aggregate, replacement of cement with Metakaolin and class $F$ flyash, combinations of both and controlled SCC mix with 0.36 water/cementitious ratio(by weight) and 388 litre $/ \mathrm{m}^{3}$ of cement paste volume. Crushed granite stones of size $16 \mathrm{~mm}$ and $12.5 \mathrm{~mm}$ are used with a blending 60:40 by percentage weight of total coarse aggregate. Detailed steps are discussed in this study for the SCC and its mortar.
\end{abstract}

Keywords - Self compacting concrete, Metakaolin, Flyash, mixdesign, simple tool

\section{INTRODUCTION}

Self-compacting concrete (SCC) is an innovative concrete that does not require vibration for placing and compaction. It is able to flow under its own weight, completely filling formwork and achieving full compaction, even in the presence of congested reinforcement. The hardened concrete is dense, homogeneous and has the same engineering properties and durability as traditional vibrated concrete.

Concrete that requires little vibration or compaction has been used in Europe since the early 1970s but self-compacting concrete was not developed until the late 1980's in Japan. In Europe it was probably first used in civil works for transportation networks in Sweden in the mid1990's. The EC funded a multi-national, industry lead project "SCC" 1997-2000 and since then SCC has found increasing use in all European countries. Self-compacting concrete offers a rapid rate of concrete placement, with faster construction times and ease of flow around congested reinforcement. The fluidity and segregation resistance of SCC ensures a high level of homogeneity, minimal concrete voids and uniform concrete strength, providing the potential for a superior level of finish and durability to the structure. SCC is often produced with low water-cement ratio providing the potential for high early strength, earlier demoulding and faster use of elements and structures.

The elimination of vibrating equipment improves the environment on and near construction and precast sites where concrete is being placed, reducing the exposure of workers to noise and vibration.

The improved construction practice and performance, combined with the health and safety benefits make .SCC a very attractive solution for both precast concrete and civil engineering construction.

In 2002 EFNARC published their "Specification \& Guidelines for Self-Compacting concrete" which, at that time, provided state of the art information for producers and users. Since then, much additional technical information on SCC has been published but European design, product and construction standards do not yet specifically refer to SCC and for site applications this has limited its wider acceptance, especially by specifiers and purchasers. In 1994 five European organisations BIBM, CEMBUREAU, ERMCO, EFCA and EFNARC, all dedicated to the promotion of advanced materials and systems for the supply and use of concrete, created a "European Project Group" to review current best practice and produce a new document covering all aspects of SCC. 


\subsection{CONCRETE MIXTURE PROPORTIONING}

A total of 11 concrete mixtures were designed and summarizes in table.11 at water-binder ratios of 0.36 with total cementitious materials content range may vary based on the replacements of Metakaolin and Flyash at different levels .Cementitious blends in which proportion of ordinary portland cement was replaced with the mineral admixtures. The replacement ratios for Metakaolin, Flyash and both MK and FA combinations including controlled mix (SCC) were $5 \%, 10 \%, 15 \%$ and $20 \%$ of Metakaolin, $10 \%, 20 \%, 30 \%$ of Flyash and combinations with MK and FA as $(5 \%+30 \%),(10 \%+20 \%)$ and $(15 \%+10 \%)$ and controlled concrete is SCC by weight of the total binder.

\subsection{SELECTION OF MIX PROPORTIONS}

In designing the SCC mix, it is most useful to consider the relative proportions of the key components by volume rather than by mass [9]. The following key proportions for the mixes listed below [15], [9], [13] and [7]:

1. Air content (by volume)

2. Coarse aggregate content (by volume)

3. Paste content (by volume)

4. Binder (cementitious) content (by weight)

5. Replacement of mineral admixture by percentage binder weight

6. Water/ binder ratio (by weight)

7. Volume of fine aggregate/ volume of mortar

8. SP dosage by percentage cementitious (binder) weight

9. VMA dosage by percentage cementitious (binder) weight

\subsection{RESEARCH SIGNIFICANCE}

A simple and user friendly tool has been developed for SCC mix design on the basis of key proportions of the constituents of SCC with or without blended cement and with or without coarse aggregate blending.

\subsection{OUTLINE OF THIS PAPER}

This paper includes the selection of mix proportions for SCC from the relevant literature, the experimental program, material properties, design of SCC mix design tool, calculation of key proportions for a given SCC scenario, evaluation of SCC mix design and conclusions.

\section{EXPERIMENTAL STUDY}

\subsection{EXPERIMENTAL PROGRAM}

According to SCC mix design with the available materials. In this study, this tool has been used to design a SCC mix having $29 \%$ of coarse aggregate content and $388 \mathrm{litre} / \mathrm{m}^{3}$ of paste volume, $5 \%, 10 \%, 15 \% \&$ $20 \%$ replacement of cement with Metakaolin and $10 \%, 20 \% \& 30 \%$ replacement with class $\mathrm{F}$ fly ash and 0.36 water/cement ratio (by weight). Crushed granite stones of size $16 \mathrm{~mm}$ and $12.5 \mathrm{~mm}$ are used with the blending 60:40 by percentage weight of total coarse aggregate.

\subsection{MATERIAL PROPERTIES}

This section will present the chemical and physical properties of the ingredients. Bureau of Indian Standards (IS) and American Society for Testing and Materials (ASTM) procedures were followed for determining the properties of the ingredients in this investigation.

\subsubsection{CEMENT}

Ordinary Portland Cement 43 grade was used corresponding to IS-8112(1989).The specific gravity of cement is 3.15 .

\subsubsection{CHEMICAL ADMIXTURES}

Sika Viscocrete 10R3 is used as high performance super plasticizer (HPSP) cum retarder and Percentage of dry material in SP and VMA is $40 \%$.

\subsubsection{ADDITIVE OR MINERAL ADMIXTURE}

Metakaolin manufactured from pure raw material to strict quality standards. Metakaolin is a high quality pozzolanic material, which blended with Portland cement in order to improve the strength and durability of concrete and mortars. Metakaolin removes chemically reactive calcium hydroxide from the hardened cement paste. It reduces the porosity of hardened concrete. Metakaolin densified and reduces the thickness of the interfacial zone, this improving the adhesion between the hardened cement paste and particulars of sand or aggregate. Metakaolin procured from 20 Microns company Vadodara, Gujarat, India and Class F fly ash from Rayalaseema Thermal 
Power Plant (RTPP), Muddanur, A.P.India is used as additives according to ASTM C 618 [5]. As per IS456(2000) [6], cement is replaced by weight of material. The specific gravity of Metakaolin is 2.5 and fly ash is 2.12 .

\subsubsection{COARSE AGGREGATE}

Crushed granite stones of size $16 \mathrm{~mm}$ and $12.5 \mathrm{~mm}$ are used as coarse aggregate. As per IS: 2386 (Part III)-1963 [6], the bulk specific gravity in oven dry condition and water absorption of the coarse aggregate are 2.66 and $0.3 \%$ respectively. The dry-rodded unit weight (DRUW) of the coarse aggregate with the coarse aggregate blending 60:40 (16mm and 12.5mm) as per IS: 2386 (Part III) 1963 [4] is $1608 \mathrm{~kg} / \mathrm{m}^{3}$.

\subsubsection{FINE AGGREGATE}

Natural river sand is used as fine aggregate. As per IS: 2386 (Part III)-1963 [6], the bulk specific gravity in oven dry condition and water absorption of the sand are 2.6 and $1 \%$ respectively.

\subsubsection{WATER}

Ordinary tap water is used

\section{DESIGN OF SELF COMPACTING CONCRETE MIX DESIGN TOOL}

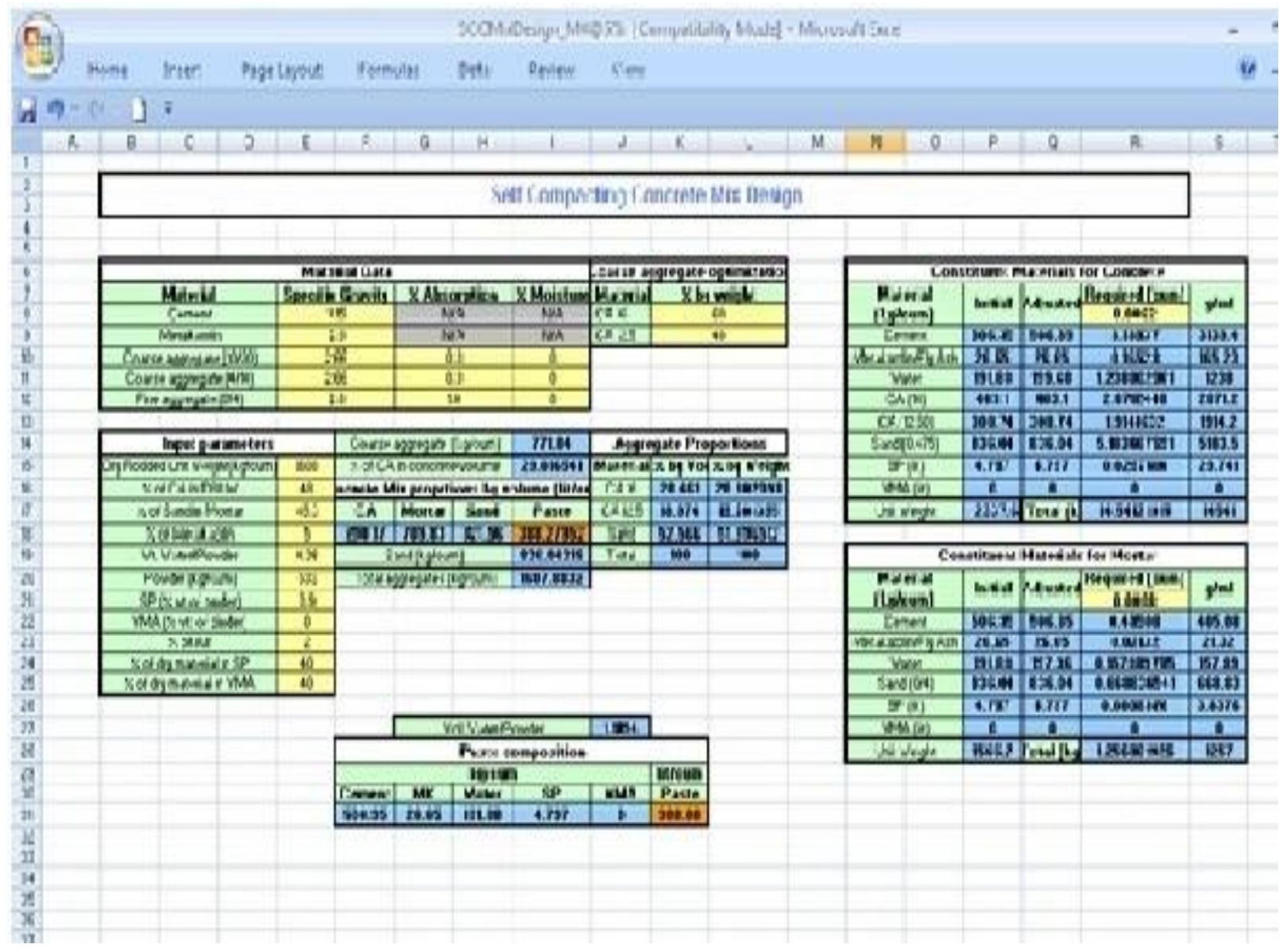

\subsection{MATERIAL PROPERTIES FOR SCC MIX DESIGN TOOL}

The following material properties for the SCC mix design tool are to be determined as shown in Table1.

1. Specific gravity of cement, Metakaolin, fly ash, coarse aggregate and fine aggregate.

2. Percentage of water absorption of coarse and fine aggregates.

3. Percentage of moisture content in coarse and fine aggregates.

4. Dry-rodded unit weight (DRUW) of coarse aggregate for the particular coarse aggregate blending.

5. Percentage of dry material in SP cum retarder. 
Table 1. MATERIAL PROPERTIES

\begin{tabular}{|c|c|c|c|}
\hline Material & Specific Gravity & \% Absorption & \% Moisture \\
\hline Cement & 3.15 & N/A & N/A \\
\hline Additive - Metakaolin & 2.5 & N/A & N/A \\
\hline Additive-Flyash & 2.12 & N/A & N/A \\
\hline Coarse aggregate (CA1 16mm) & 2.66 & 0.3 & 0 \\
\hline Coarse aggregate (CA2 $12.5 \mathrm{~mm})$ & 2.66 & 0.3 & 0 \\
\hline Fine aggregate (Sand) & 2.6 & 1.06 & 0 \\
\hline
\end{tabular}

\subsection{DETAILED STEPS FOR SCC MIX DESIGN TOOL}

The detailed steps for mix design are described as follows:

1. Assume air content by percentage of concrete volume.

2. Input the coarse aggregate blending by percentage weight of total coarse aggregate.

3. Input the percentage of coarse aggregate in DRUW to calculate the coarse aggregate volume in the concrete volume.

4. Adjust the percentage of fine aggregate volume in mortar volume.

5. Obtain the required paste volume.

6. Adopt suitable water/ binder ratio by weight.

7. Input the percentage replacement of fly ash by weight of cementitious material.

8. Input the dosage of SP cum retarder by percentage weight of binder.

9. Adjust the binder (cementitious material) content by weight to obtain the required paste. The coarse aggregate optimization is shown in Table 2. The input parameters section is shown in Table 3.

Table 2. COARSE AGGREGATE OPTIMIZATION OR BLENDING

\begin{tabular}{|l|c|}
\hline \multicolumn{2}{|l|}{ Coarse aggregate optimization } \\
\hline Material & \% by weight \\
\hline CA1 $16 \mathrm{~mm}$ & 60 \\
\hline CA2 $12.5 \mathrm{~mm}$ & 40 \\
\hline
\end{tabular}

Table 3. INPUT PARAMETERS

\begin{tabular}{|c|c|}
\hline \multicolumn{2}{|c|}{ Input parameters } \\
\hline Dry Rodded Unit Weight(kg/cum) & 1608 \\
\hline \% of CA in DRUW & 48 \\
\hline \% of Sand in Mortar & 45.3 \\
\hline \% of Metakaolin & 5 \\
\hline Wt. Water/Powder & 0.36 \\
\hline Powder (kg/cum) & 533 \\
\hline SP (\% wt.of binder) & 0.9 \\
\hline VMA (\% wt. of binder) & 0 \\
\hline \% of Air & 2 \\
\hline \% of dry material in SP cum retarder & 40 \\
\hline \% of dry material in VMA & 0 \\
\hline
\end{tabular}

\subsection{OUTPUT CONSTITUENT MATERIALS FOR SCC}

After giving all the necessary data, the tool automatically calculates and shows the required out put. Concrete mix proportions by volume and total aggregate by weight are shown in Table 4 . 
Table 4. CONCRETE MIX PROPORTIONS BY VOLUME

\begin{tabular}{|c|c|c|c|}
\hline \multicolumn{3}{|c|}{ Coarse aggregate $(\mathrm{kg} / \mathrm{cum})$} & 771.84 \\
\hline \multicolumn{3}{|c|}{$\%$ of CA in concrete volume } & 29.01654 \\
\hline \multicolumn{4}{|c|}{ Concrete Mix proprtions by volume (lit/cum) } \\
\hline CA & Mortar & Sand & Paste \\
\hline 290.1654 & 709.8346 & 321.5551 & 388.2795 \\
\hline \multicolumn{3}{|c|}{ Sand (kg/cum) } & 836.0431 \\
\hline \multicolumn{3}{|c|}{ Total aggregates $(\mathrm{kg} / \mathrm{cum})$} & 1607.8831 \\
\hline
\end{tabular}

Paste composition is shown in Table 5. Constituent materials for SCC are shown in Table 6. Constituent materials for SCM are shown in Table 7. This tool also displays the constituent materials for the required volume of SCC or SCM as shown in Table 6 and Table 7. Aggregate proportions by volume and by weight are shown in Table 8.

Table 5. PASTE COMPOSITION

\begin{tabular}{|c|c|c|c|c|c|}
\cline { 2 - 5 } \multicolumn{1}{c|}{ Vol. Water/Powder } & 1.119447 & \multicolumn{1}{c|}{ Paste composition } \\
\hline \multicolumn{5}{c|}{ kg/cum } \\
\hline Cement & MK & Water & $\begin{array}{c}\text { SP cum } \\
\text { retarder }\end{array}$ & VMA & Paste \\
\hline 506.35 & 26.65 & 191.88 & 4.797 & 0 & 388.083 \\
\hline
\end{tabular}

Table 6.CONSTITUENT MATERIALS FOR SCC

\begin{tabular}{|c|c|c|c|c|}
\hline \multicolumn{5}{|c|}{ Constituent Materials for Concrete } \\
\hline $\begin{array}{c}\text { Material } \\
\text { (kg/cum) }\end{array}$ & Initial & Adjusted & Required (cum) & \multirow{2}{*}{ g/ml } \\
\cline { 4 - 5 } Cement & $\mathbf{5 0 6 . 3 5}$ & $\mathbf{5 0 6 . 3 5}$ & $\mathbf{3 . 1 3 9 3 7}$ & $\mathbf{3 1 3 9 . 3 7}$ \\
\hline Metakaolin & $\mathbf{2 6 . 6 5}$ & $\mathbf{2 6 . 6 5}$ & $\mathbf{0 . 1 6 5 2 3}$ & $\mathbf{1 6 5 . 2 3}$ \\
\hline Water & $\mathbf{1 9 1 . 8 8}$ & $\mathbf{1 9 9 . 6 7 7 8}$ & $\mathbf{1 . 2 3 8 0 0 2 0 6 1}$ & $\mathbf{1 2 3 8 . 0 0 2}$ \\
\hline CA (16) & $\mathbf{4 6 3 . 1 0 4}$ & $\mathbf{4 6 3 . 1 0 4}$ & $\mathbf{2 . 8 7 1 2 4 4 8}$ & $\mathbf{2 8 7 1 . 2 4 5}$ \\
\hline CA (12.50) & $\mathbf{3 0 8 . 7 3 6}$ & $\mathbf{3 0 8 . 7 3 6}$ & $\mathbf{1 . 9 1 4 1 6 3 2}$ & $\mathbf{1 9 1 4 . 1 6 3}$ \\
\hline Sand (0.475) & $\mathbf{8 3 6 . 0 4 3 2}$ & $\mathbf{8 3 6 . 0 4 3 2}$ & $\mathbf{5 . 1 8 3 4 6 7 6 9 1}$ & $\mathbf{5 1 8 3 . 4 6 8}$ \\
\hline SP (lit) & 4.797 & 4.797 & $\mathbf{0 . 0 2 9 7 4 1 4}$ & $\mathbf{2 9 . 7 4 1 4}$ \\
\hline VMA (lit) & $\mathbf{0}$ & $\mathbf{0}$ & $\mathbf{0}$ & $\mathbf{0}$ \\
\hline Unit Weight & $\mathbf{2 3 3 7 . 5 6}$ & Total (kg) & $\mathbf{1 4 . 5 4 1 2 1 9 1 5}$ & $\mathbf{1 4 5 4 1 . 2 2}$ \\
\hline
\end{tabular}

\begin{tabular}{|c|c|c|c|c|}
\hline \multicolumn{5}{|c|}{ Constituent Materials for Mortar } \\
\cline { 1 - 2 } $\begin{array}{c}\text { Material } \\
\text { (kg/cum) }\end{array}$ & Initial & Adjusted & Required (cum) & \multirow{2}{*}{ g/ml } \\
\cline { 4 - 5 } Cement & $\mathbf{5 0 6 . 3 5}$ & $\mathbf{5 0 6 . 3 5}$ & $\mathbf{0 . 0 0 0 8}$ & \\
\hline Metakaolin & $\mathbf{2 6 . 6 5}$ & $\mathbf{2 6 . 6 5}$ & $\mathbf{0 . 0 2 1 3 2}$ & $\mathbf{2 1 . 3 2}$ \\
\hline Water & 191.88 & 197.3622 & $\mathbf{0 . 1 5 7 8 8 9 7 8 5}$ & $\mathbf{1 5 7 . 8 8 9 8}$ \\
\hline Sand (0/4) & $\mathbf{8 3 6 . 0 4 3 2}$ & $\mathbf{8 3 6 . 0 4 3 2}$ & $\mathbf{0 . 6 6 8 8 3 4 5 4 1}$ & $\mathbf{6 6 8 . 8 3 4 5}$ \\
\hline SP (lit) & 4.797 & 4.797 & $\mathbf{0 . 0 0 3 8 3 7 6}$ & $\mathbf{3 . 8 3 7 6}$ \\
\hline VMA (lit) & $\mathbf{0}$ & $\mathbf{0}$ & $\mathbf{0}$ & $\mathbf{0}$ \\
\hline Unit Weight & $\mathbf{1 5 6 5 . 7 2}$ & Total (kg) & $\mathbf{1 . 2 5 6 9 6 1 9 2 6}$ & $\mathbf{1 2 5 6 . 9 6 2}$ \\
\hline
\end{tabular}




\section{CALCULATION OF KEY PROPORTIONS}

The detailed steps for calculation of key proportions are presented below with an example. The interface of SCC mix design tool for the mix 29_60:40 is shown in Figure 1.

\section{SCC MIX SCENARIO}

A SCC mix with $29 \%$ coarse aggregate content of concrete volume with a paste volume of $388 \mathrm{litre} / \mathrm{m}^{3}$ have been designed for water/ binder ratio 0.36 (by weight). Cement has been replaced with $5 \%, 10 \%, 15 \%$ and $20 \%$ of Metakaolin and $10 \%, 20 \%$ and 30\% of Class F fly ash and combinations of both Metakaolin and Flyash by percentage weight of cementitious material. Coarse aggregate of sizes $16 \mathrm{~mm}$ and $12.5 \mathrm{~mm}$ with coarse aggregate blending 60:40 by percentage weight of total aggregate are used in this mix. High performance superplasticizer cum retarder are used. All the material properties and input parameters are shown in Table 1 and Table 3. Air content assumed as $2 \%$ of concrete volume.

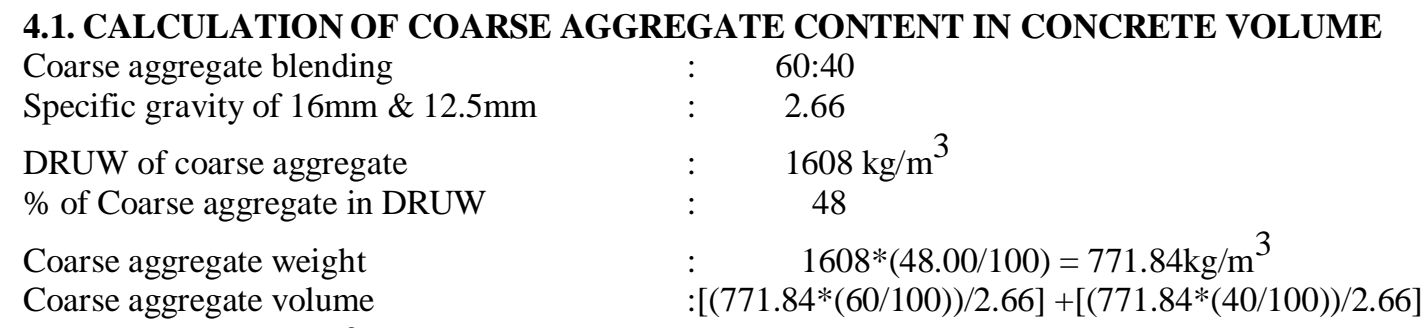

\subsection{CALCULATION OF MORTAR VOLUME}

Mortar Volume

\subsection{CALCULATION OF SAND VOLUME}

$\%$ of sand in Mortar volume

Sand Volume

\subsection{CALCULATION OF PASTE VOLUME}

Paste Volume

$$
\text { Concrete volume-coarse aggregate volume }
$$$$
1000-290.0165=709.8346 \mathrm{litre} / \mathrm{m}^{3}
$$

45.30

$709.8346 *(45.30 / 100)=321.5551$ litre $/ \mathrm{m}^{3}$

Mortar volume-sand volume

$7098346-321.5551=388.2795 \mathrm{litre} / \mathrm{m}^{3}$

\subsection{CAlCUlation OF PASTE COMPOSITION}

Specific gravity of cement

Specific gravity of Metakaolin

Air content

Water/ binder ratio (by weight)

$\%$ of Metakaolin by weight of binder

$\%$ of SP by weight of binder

Binder

Metakaolin

Cement

Water

Volume of cement

Volume of Metakaolin

SP

Total Paste volume
3.15

2.50

$2 \%=20$ litre $/ \mathrm{m}^{3}$

0.36

5

0.9

$$
533 \mathrm{~kg} / \mathrm{m}^{3}
$$$$
533 *(5 / 100)=26.65 \mathrm{~kg} / \mathrm{m}^{3}
$$$$
533-26.65=506.65 \mathrm{~kg} / \mathrm{m}^{3}
$$$$
533 * 0.36=191.88 \text { litre } / \mathrm{m}^{3}
$$$$
506.35 / 3.15=160.746 \mathrm{litre} / \mathrm{m}^{3}
$$$$
26.65 / 2.50=26.65 \text { litre } / \mathrm{m}^{3}
$$$$
533 *(0.9 / 100)=4.797 \mathrm{litre} / \mathrm{m}^{3}
$$

Volume of (cement+fly ash+Water+SP+ Air) $(506.35 / 3.15)+(26.65 / 2.50)+191.88+4.797+2 * 10$ $=388.0831$ litre $/ \mathrm{m}^{3}$ 
In the tool, the binder has been adjusted to $533 \mathrm{~kg} / \mathrm{m}^{3}$ in order to obtain the required paste volume of about 388.083 litre $/ \mathrm{m}^{3}$ (say $388 \mathrm{litre} / \mathrm{m}^{3}$ ).

\subsection{CALCULATION OF CONSTITUENT MATERIALS FOR CONCRETE}

Specific gravity of sand 2.6

$\%$ of absorption of $20 \mathrm{~mm}$

0.3

$\%$ of absorption of $10 \mathrm{~mm}$

0.3

$\%$ of absorption of sand

1.0

$\%$ of moisture in $20 \mathrm{~mm}$

0.0

$\%$ of moisture in $10 \mathrm{~mm}$

0.0

$\%$ of moisture in sand

0.0

$\%$ of dry material in SP

40

Cement

$506.35 \mathrm{~kg} / \mathrm{m}^{3}$

Metakaolin

$26.35 \mathrm{~kg} / \mathrm{m}^{3}$

Initial water content

191.88 litre $/ \mathrm{m}^{3}$

Coarse aggregate

$771.84 \mathrm{~kg} / \mathrm{m}^{3}$

$16 \mathrm{~mm}$ coarse aggregate (CA1)

$771.84 *(60 / 100)=463.104 \mathrm{~kg} / \mathrm{m}^{3}$

$12.5 \mathrm{~mm}$ coarse aggregate (CA2)

$771.84 *(40 / 100)=308.736 \mathrm{~kg} / \mathrm{m}^{3}$

Sand

$321.5551 * 2.6=836.043 \mathrm{~kg} / \mathrm{m}^{3}$

Adjusted water content $=$ Initial water $-[C A 1 *(\%$ of moisture $-\%$ of absorption $) / 100]$

- [CA2* $(\%$ of moisture - $\%$ of absorption $) / 100]$

- [sand*(\% of moisture - \% of absorption)/100]

- [SP*(100-\%of dry material in SP)/100]

$=191.88-[463.104 *(0-0.3) / 100]-[291.67 *(0-0.3) / 100]$

- [836.043*(0-1)/100]-[4.797*(100-40)/100]

$=199.6778 \mathrm{litre} / \mathrm{m}^{3}$

Adjusted 16mm coarse aggregate

$\mathrm{CA} 1 *[1+(\%$ of moisture/100) $]$

$463.104 *[1+(0 / 100)]=\mathbf{4 6 3 . 1 0 4} \mathrm{kg} / \mathrm{m}^{3}$

Adjusted $12.5 \mathrm{~mm}$ coarse aggregate

: $\quad \mathrm{CA} 2 *[1+(\%$ of moisture/100) $]$

308.735* $[1+(0 / 100)]=\mathbf{3 0 8 . 7 3 5} \mathrm{kg} / \mathrm{m}^{3}$

Adjusted sand

sand*[1+(\% of moisture/100)]

308.735 $*[1+(0 / 100)]=\mathbf{3 0 8 . 7 3 5} \mathrm{kg} / \mathrm{m}^{3}$

\subsection{CALCULATION OF CONSTITUENT MATERIALS FOR MORTAR}

Coarse aggregate contribution should not be considered in the adjustment of water. The remaining constituents are already discussed in the section 4.6.

Initial water content

$191.88 \mathrm{litre} / \mathrm{m}^{3}$

Adjusted water content $=$ Initial water $-[$ sand $*(\%$ of moisture $-\%$ of absorption $) / 100]$

- [SP*(100-\%of dry material in SP)/100]

$=191.88-[836.043 *(0-1) / 100]-[4.797 *(100-40) / 100]$

$=197.36 \mathrm{litre} / \mathrm{m}^{3}$

\subsection{PROPORTIONS}

Mix types with percentage relative proportions and mix proportions of constituent materials are shown in Table 9 and Table 10. 
Table 9. PERCENTAGE RELATIVE PROPORTIONS OF SCC MIX

\begin{tabular}{|c|c|c|c|c|c|c|}
\hline \multicolumn{5}{|c|}{ Cementitious Material - OPC+5\% Metakaolin } & \multicolumn{2}{|c|}{$\mathrm{w} / \mathrm{cm}-\mathbf{0 . 3 6}$} \\
\hline \multirow[t]{2}{*}{ Mix Type } & \multirow{2}{*}{\multicolumn{2}{|c|}{$\begin{array}{c}\text { Coarse Aggregate } \\
\text { Blending } \\
\text { Percentage By } \\
\text { Weight } \\
\text { (20 mm and } 10\end{array}$}} & $\begin{array}{c}\text { Percentage } \\
\text { of Coarse } \\
\text { aggregate }\end{array}$ & $\begin{array}{c}\text { Percentage } \\
\text { of } \\
\text { Mortar }\end{array}$ & $\begin{array}{c}\text { Percen } \\
\text { tage } \\
\text { of } \\
\text { Sa }\end{array}$ & $\begin{array}{l}\text { Percentage of } \\
\text { Paste }\end{array}$ \\
\hline & & & \multicolumn{4}{|c|}{ By Volume } \\
\hline $29 \_60: 40^{\mathrm{a}}$ & 6 & 40 & 29.01654 & $\mathbf{7 0 . 9 8 3 4 6}$ & 32.15551 & 38.8279 \\
\hline
\end{tabular}

29_60:40: where 28 is the percentage of coarse aggregate volume in a concrete mix

$60: 40$ is the coarse aggregate blending by percentage weight of $16 \mathrm{~mm}$ and $12.5 \mathrm{~mm}$ resp.

Table 10. MIX PROPORTIONS OF CONSTITUENT MATERIALS

\begin{tabular}{|l|c|l|l|l|l|l|l|c|}
\hline Mix Type & $\begin{array}{l}\text { Binder } \\
\mathbf{k g} / \mathbf{m}^{\mathbf{3}}\end{array}$ & $\begin{array}{l}\text { Cement } \\
\mathbf{K g} / \mathbf{m}^{3}\end{array}$ & $\begin{array}{l}\text { Metakaolin } \\
\mathbf{K g} / \mathbf{m}^{\mathbf{3}}\end{array}$ & $\begin{array}{l}\text { Water } \\
\mathbf{1 / \mathbf { m } ^ { 3 }}\end{array}$ & $\begin{array}{l}\mathbf{1 6 m m} \\
\mathbf{K g} / \mathbf{m}^{3}\end{array}$ & $\begin{array}{l}\mathbf{1 2 . 5 m m} \\
\mathbf{k g} / \mathbf{m}^{3}\end{array}$ & $\begin{array}{l}\text { Sand } \\
\mathbf{k g} / \mathbf{m}^{\mathbf{3}}\end{array}$ & $\begin{array}{c}\mathbf{S P} \\
\mathbf{1 / m} \mathbf{3}\end{array}$ \\
\hline $29 \_60: 40$ & 533 & 506.35 & 26.35 & 191.88 & 463.104 & 308.736 & 836.0432 & 4.797 \\
\hline
\end{tabular}

Table 11. MIX DESIGN PROPORTIONS FOR DIFFERENT COMBINATIONS

\begin{tabular}{|c|c|c|c|c|c|c|c|c|c|c|c|}
\hline \begin{tabular}{|l} 
SI. \\
No.
\end{tabular} & $\begin{array}{l}\text { Designation } \\
\text { of Mix } \\
\text { Proportion }\end{array}$ & \begin{tabular}{|l} 
Total \\
Binder \\
$\left(\mathrm{Kg} / \mathrm{m}^{3}\right)$
\end{tabular} & $\begin{array}{l}\text { Cement } \\
\left(\mathrm{Kg} / \mathrm{m}^{3}\right)\end{array}$ & $\begin{array}{l}\text { Metakao } \\
\operatorname{lin} \\
\left(\mathrm{Kg} / \mathrm{m}^{3}\right)\end{array}$ & $\begin{array}{l}\text { Flyash } \\
\left(\mathrm{Kg} / \mathrm{m}^{3}\right)\end{array}$ & $\begin{array}{l}\text { F.A } \\
\left(\mathrm{Kg} / \mathrm{m}^{3}\right)\end{array}$ & $\begin{array}{l}\text { C.A } \\
\left(\mathrm{Kg} / \mathrm{m}^{3}\right)\end{array}$ & $\begin{array}{l}\text { Water } \\
\left(\mathbf{K g} / \mathbf{m}^{3}\right)\end{array}$ & $\begin{array}{l}\text { S.P. } \\
(\%)\end{array}$ & $\begin{array}{l}\text { S.P } \\
\left(\mathrm{Kg} / \mathrm{m}^{3}\right)\end{array}$ & $\begin{array}{l}\text { W/P } \\
\text { ratio }\end{array}$ \\
\hline 1 & MK5 & 533.00 & 506.35 & 26.65 & ----- & 836 & 771.84 & 191.88 & 0.9 & 4.797 & 0.36 \\
\hline 2 & MK10 & 530.00 & 477.00 & 53.00 & ----- & 836 & 771.84 & 190.80 & 0.9 & 4.770 & 0.36 \\
\hline 3 & MK15 & 527.00 & 447.95 & 79.05 & ----- & 836 & 771.84 & 189.72 & 0.9 & 4.743 & 0.36 \\
\hline 4 & MK20 & 523.50 & 418.80 & 105.00 & ----- & 836 & 771.84 & 188.46 & 0.9 & 4.712 & 0.36 \\
\hline 5 & FA10 & 524.50 & 472.00 & $\begin{array}{l}---- \\
\end{array}$ & 52.45 & 836 & 771.84 & 188.82 & 0.9 & 4.721 & 0.36 \\
\hline 6 & FA20 & 513.50 & 410.80 & $\begin{array}{ll}---- \\
\end{array}$ & 102.70 & 836 & 771.84 & 184.86 & 0.9 & 4.622 & 0.36 \\
\hline 7 & FA30 & 502.00 & 351.75 & ----- & 150.75 & 836 & 771.84 & 180.90 & 0.9 & 4.523 & 0.36 \\
\hline 8 & MK5+FA30 & 499.50 & 324.68 & 25.00 & 149.85 & 836 & 771.84 & 179.82 & 0.9 & 4.500 & 0.36 \\
\hline 9 & MK10+FA20 & 507.50 & 355.25 & 50.75 & 101.50 & 836 & 771.84 & 182.70 & 0.9 & 4.570 & 0.36 \\
\hline 10 & MK15+FA10 & 504.00 & 378.00 & 75.60 & 50.40 & 836 & 771.84 & 181.44 & 0.9 & 4.536 & 0.36 \\
\hline 11 & SCC & 536.00 & 536.00 & ----- & ----- & 836 & 771.84 & 192.96 & 0.9 & 4.824 & 0.36 \\
\hline
\end{tabular}

V.

CONCLUSIONS

The following conclusions can be drawn on the basis of SCC mix design tool Self-Compacting Concrete is considered to be the most promising building material for the expected revolutionary changes on the job site as well as on the desk of designers and civil engineers.

Self compacting concrete mix design tool is developed based on the key proportions of the constituents. This tool is very simple and user friendly for the self compacting concrete mix design. It can be used for the SCC mix with or without blended cement and coarse aggregate with or without coarse aggregate blending. This tool can also be enhanced for multi blended cements with more additives and also useful for Self compacting mortar design. It displays all necessary data for SCC mix design and also displays constituent materials for SCC or SCM for the required volume. 


\section{REFERENCES}

[1] IS: 3812-2003, Specifications for Pulverized fuel ash, Bureau of Indian Standards, New Delhi, India.

[2] IS: 8112-1989, Specifications for 43 grade Portland cement, Bureau of Indian Standards, New Delhi, India.

[3] IS: 383-1970, Specifications for Coarse and Fine aggregates from Natural sources for Concrete, Bureau of Indian Standards, New Delhi, India.

[4] American Concrete Institute. "Self-Consolidating Concrete", ACI 237R-07.

[5] American Society for Testing and Materials. "Standard specification for coal fly ash and raw or calcined natural pozzolan for use in concrete", ASTM C 618 (2003).

[6] Bureau of Indian Standards. "Plain and reinforced concrete code for practice", IS-456 (2000), New Delhi.

[4] Bureau of Indian Standards. "Methods of test for aggregates for concrete. Specific gravity, Density, Voids, Absorption and Bulking", IS-2386 (Part III, 1963).

[7] Domone PLJ. 2006b. "Self-compacting concrete: An analysis of 11 years of case studies". Cement and Concrete Composites 28(2):197-208.

[8] EFNARC (European Federation of national trade associations representing producers and applicators of specialist building products), Specification and Guidelines for self- compacting concrete, February 2002, Hampshire, U.K.

[9] EFNARC. "Specification and guidelines for self-compacting concrete. European Federation of Producers and Applicators of Specialist Products for Structures", 2002.

[10] RILEM TC 174 SCC. "Self compacting concrete State-of-the-art report of RILEM technical committee 174-SCC". Skarendahl A, Petersson O, editors, RILEM Publications S.A.R.L., France, 2000.

[11]Ghazi F Kheder, Rand S Al Jaidiri. 2010. "New Method for Proportioning Self-Consolidating Concrete Based onCompressive Strength Requirements". ACI Materials 107(5):490-497.

[12] Goodier C. 2001. "Self-Compacting Concrete". European Network of Building Research Institutes (ENBRI). $17: 6$

[13] Khayat KH. 1998. Viscosity-enhancing admixtures for cement-based materials - An overview. Cement and Concrete Composites, No.20, 2-3: 171-188.

[14] Newman J, Choo BS. Advanced concrete technology concrete properties. Elsevier Butterworth Heinemann, 2003.

[15] Okamura H, Ozawa K. 1995. "Mix design for self-compacting concrete". Concrete Library of Japanese Society of Civil Engineers 25(6):107-120.

[16] Okamura H, Ouchi M. 1999. "Self-compacting concrete development, present use and future". In: The 1st International RILEM Symposium on Self-Compacting Concrete. Skarendahl A, Petersson O, editors, RILEM Publications. S.A.R.L, France. 3-14.

[17] Ozawa K, Maekawa K, Kunishima M, Okamura H. 1989. "Development of high performance concrete based on the durability design of concrete structures". 445-450.

[18] Nagamoto N., Ozawa K., Mixture properties of Self-Compacting, High-Performance Concrete, Proceedings, Third CANMET/ACI International Conferences on Design and Materials and Recent Advances in Concrete Technology, SP- 172, V. M. Malhotra, American Concrete Institute, Farmington Hills, Mich. 1997, p. 623-637.

[19] Khayat K.H., Ghezal A., Utility of Statistical models in Proportioning Self-Compacting Concrete, Proceedings, RILEM

[20] International symposium on Self-Compacting Concrete, Stockholm, 1999, p. 345-359.

[21] Okamura H., Ozawa K., Mix Design for Self-Compacting Concrete, Concrete Library of Japanese Society of Civil Engineers, June 25, 1995, p. 107-120.

[22] Nagataki S., Fujiwara H., Self-Compacting property of Highly-Flowable concrete, Second Conference on advances in Concrete Technology, ACI SP-154,V.M. Malhotra, American Concrete Institute, June 1995, p. 301-304.

[22] Khayat K.H., Manai K., Lesbetons autonivlants : proprietes, charcterisation et applications , colloque sur les betons autonivlants, Universite de Sherbroke, Canada, November 1996, p. 8.

[23] Petersson O., Billberg P., Van B.K., A model for Self-Compacting Concrete, Proceedings of Production Methods and Workability of Concrete,1996, E \& FN Span, London, p. 483- 492. 